\title{
The Resolution of International Trade Disputes through Arbitration
}

\author{
Nufaris Elisa \\ University of Amir Hamzah, Medan, Indonesia \\ Email: nurfariselisa5@gmail.com
}

\begin{abstract}
:
If an international trade dispute occurs, so that the ways of resolution can be reached through non-litigation (alternative litigation) or Alternative Dispute Resolution (ADR). The facilities classified as ADR other than Arbitration facilities as contained in Article 6 of Law No. 30 of 1999 concerning Arbitration and Alternative Dispute Resolution which includes facilities including Meditation facilities, Negotiation facilities, Consolidation facilities, and other facilities. Based on the Arbitration Law it provides an opportunity to resolve trade disputes through the Arbitration institution and it is very appropriate if this institution has a very important role in resolving disputes that occur in the world of international trade. The scope of disputes which can be tried in a trial of the International Commercial Arbitration institution must be related to the issue of trade, finance and general trading (commerce), while those relating to other matters have nothing to do at all.
\end{abstract}

Keywords:

disputes; trade; arbitration

\section{Introduction}

In the world of national and international trade there is often a dispute between the parties, both caused by differences in interpretation of the terms of the agreement made and because of differences in understanding of the ways in which the contents of the agreement are intended.

Conflict resolution is conventionally carried out through the courts. However, over time this judicial body is increasingly stuck in juridical walls that are difficult to penetrate by justice seekers, especially if the justice seeker is a business person, with disputes concerning business. Then began to think about other alternatives to resolve disputes, including through the arbitration body.

Arbitration is an old way to settle disputes, a way that has been recognized by some of the world community. In the trading business world, they generally use the arbitration institutions more in resolving business and trade disputes that occur between them, rather than resolving them through litigation or judicial institutions.

The only advantage of arbitration against a court is the nature of its confidentiality, because its decision is not made public. For this reason, dispute resolution through arbitration is more desirable than through justice, especially for international business or trade contracts.

\subsection{Formulation of the Problem}

Based on the background above, the problem are:

1. What is the role of the Arbitration institution in resolving international trade disputes?

2. What is the scope of disputes that occur in the world of trade that can be tried in an International Arbitration court hearing? 
3. What is the jurisdiction of the Arbitration tribunal for disputes arising in the world of international trade?

\subsection{Writing Purpose}

1. To find out the role of the arbitration institution in resolving international trade disputes.

2. To find out the scope of disputes that occur in the world of international trade that can be heard in an arbitration tribunal.

3. To find out the jurisdiction of the arbitration tribunal for disputes arising in the world of international trade.

\subsection{Writing Method}

In discussing this paper the writer uses the library study method. The discussion is carried out through a review of the existing literature.

\section{Review of Literature}

\subsection{Definition of Arbitration}

The word arbitration comes from the words arbitrate (Latin), Arbitrage (Dutch), arbitration (English), Schiedspruch (German), and Arbitrage (French), which means the power to resolve things according to wisdom or peace of deb arbiter or referee.

According to the general Indonesian dictionary referred to as Arbitration is a refereeing body outside the general court. According to the complete economic dictionary, arbitration (dispute resolution) is a procedure of dispute resolution, generally disputes in the field of industry in which a neutral party becomes a third party or arbitrator, after hearing the explanations of the two disputing parties, a binding decision is issued for both parties. This procedure is commonly used if normal negotiations that have been carried out fail to resolve the problem. In the UK the task for this is Advisory, Conalation and Arbitration Service (ACAS).

In Law No. 30 of 1999 concerning Arbitration and Alternative Dispute Resolution, authentic arbitration limits are also given. Article 1 number 1 defines what is meant by arbitration is a way to settle a civil dispute outside the general court based on an arbitration agreement made in writing by the parties to the dispute.

There are two types of arbitration, which the parties can choose to resolve the dispute. The two types of arbitration are:

\section{a. Arbitration of Ad Hoc (Vaunter)}

Arbitration which is not coordinated by an Arbitration institution and is specifically or incidentally formed to examine and decide certain dispute resolution within a certain period of time.

\section{b. Arbitration of Institutional}

Institutional Arbitration established and attached to a particular body or institution. Permanent and permanent nature is formed to resolve disputes that occur as a result of the implementation of the agreement.

\subsection{The Role of Arbitration as an International Legal Entity}

Today the role of the International Commercial Arbitration institution is increasingly important in resolving international trade disputes. Almost every day this International 
Commercial Arbitration takes place in various places in the world.

There are several reasons why the Arbitration resolution method is preferred over the resolution in court, namely that in general the National Courts lack the confidence of the ruling international business community.

Instead the International Commercial Arbitration is an 'Employers' Court' that exists to settle disputes between according to their needs and desires. As we know, holding a trial through an ordinary court (the national court of a country) is considered ineffective for the business community, because of the problems of the suspension of the case and also the congress (the case arrears must be resolved).

In addition, the issuance of a court decision does not automatically result in the case being completed. Because it is still possible for parties who are dissatisfied with the decision to submit their case to a higher court.

The logical consequence of litigation through an ordinary court is that the costs incurred are certainly greater than the costs of cheaper Arbitration. Another advantage in the arbitration process is that it does not concern the many formalities that are found in the ordinary court proceedings. The Arbitrators in this case are not bound by the rules of the litigation process as is the case with the National Court.

\subsection{The Development of Legal Provisions Regarding Arbitration in Indonesia}

In Indonesia, it has a long development. This is due to the fact that the arbitration has been known in the laws and regulations since the publication of the Dutch Civil Procedure Code in Indonesia, that is, since the entry into force of the R.V. Even so, institutionally the history of the development of Arbitration in Indonesia gained momentum with the formation of the Indonesian National Arbitration Board on December 3, 1977. The stages of the development of the legal provisions regarding Arbitration can be made in 5 stages, namely:

a. Arbitration Law provisions according to R.V

b. Arbitration Law provisions according to H.I.R

c. Arbitration Law provisions according to the Basic Law for Judicial Power.

d. Arbitration Law provisions according to the Supreme Court Law. Provisions

e. Arbitration Law according to Law No. 30 of 1999.

For more details, these stages will be discussed one by one.

\section{Discussion}

\subsection{The Use of Indonesian Law in International Arbitration Forums}

After in 1968 signing the Convention on the resolution of disputes concerning investors between the state and citizens of other countries (Convention on the Resolution of Investment Disputes Between States and Nationals of Other States), the Law Between States and Nationals of Other States, Law 1968 No. 5 L.N 1968/32 which gave birth to the International Center for the Settlement of Investment Disputes (ICSID) in Washington, under the auspices of the World Bank. So for the first time Indonesia in 1981 was drawn before the International Arbitration forum concerned. The foreign investor who built the Kartika Plaza Hotel in Jakarta, raised the matter before the ICSID Board of Trustees. One thing and another based on the existence of foreign investors and agreed by the Government of the Republic of Indonesia in article IX has been determined that if there is a dispute between the parties, then this dispute will be resolved through arbitration before the International Center 
for Resolution of Investment Disputers in Washington, where the state of Indonesia and the state investor (in this case the United States) have become members.

The dispute that arose was regarding the revocation of the investment license (BKPM) at that time (1980). Revocation of this license is considered by the investor, Amco Asia Corporation, as an act that harms them. The plaintiffs see that their property rights have been revoked and therefore the Indonesian side is deemed to have committed acts that violated the law and violated the agreement, so that this foreign investor was demanded to be compensated by magic. The demands filed amounted to \pm US $\$ 16,000,000$. Foreign investors consisting of plaintiffs - Amco Asia Corporation, Pan American Development Limited and PT. Amco Indonesia has submitted a lawsuit to the ICSID Secretary General on January 15, 1981. They postulated that they wanted to request an Arbitration regarding a Legal Dispute, which occurred with the Republic of Indonesia.

This dispute arose directly from a hotel investment in Indonesia, the Kartika Plaza Hotel, which they had built starting in 1968. According to their proposition this investment had been approved by the Republic of Indonesia for a period of 30 years.

However, in 1980, the Republic of Indonesia, according to their argument, had revoked this investment, which was done with an armed military action '. Based on the foregoing, the plaintiffs initially demanded compensation of US $\$ 9,000,000$, in addition to interest since March 31, 1980 and the costs of Arbitration including their attorneys' fees. The number of these claims was later increased to almost 16 million US dollars (US $\$ 16,000,000$ ) after their definitive lawsuit was filed.

\subsection{The Implementation of Foreign Arbitration Award in Indonesia}

After the Republic of Indonesia Presidential Decree No. 34 dated August 5, 1981, in fact the decisions of the Foreign Arbitration could be carried out within the territory of Indonesia. With Presidential Decree No. 34 of 1981 dated August 5, 1981 this was ratified by the UN convention on the recognition and implementation of decisions of foreign (foreign) Arbitration. This convention was signed in New York on 10 June 1958 and entered into force for the countries that signed it on 7 June 1959. The Indonesian state participated in this convention by accession from 5 August 1981, namely by Presidential Decree No. 34 of 1981, State Gazette of the Republic of Indonesia of 1981 No. 40, which was notified with a letter from the President of the Republic of Indonesia dated August 5, 1981 No. R.7 / Prd / PU / XII / 1981 to the Chairperson of the Indonesian House of Representatives.

Before Presidential Decree No. 34 of 1981 there may still be doubts about the issue whether the Arbitration award that has been decided abroad can be implemented in Indonesia.

Article 2 of the Law stipulates that in the case of a dispute concerning investment concerning foreign capital. Between the Republic of Indonesia and a citizen of a foreign country, the government of the Republic of Indonesia is authorized to agree that the dispute will be submitted for resolution under the Washington Convention. Article 3 of Law No. 5 of 1968 it further provides a regulation for the implementation of the Arbitration award rendered under the auspices of the Washington Competion. This article determines, inter alia, that the implementation of an Arbitration award requires written permission to carry out the award from the Supreme Court. 
The Supreme Court must determine that the decision can be implemented. An Arbitration award, according to the Washington Convention, is not subject to a review of its contents by the Indonesian Court of Justice. However, the implementation can be rejected if the verdict is clearly violated public order.

The original text of the 1958 New York convention was The Convention on the Recognation and Enforcement of Foreign Arbitration Awards (Convention on the recognition and implementation of foreign Arbitration awards). Arbitration experts, for example Alan Redfern and Martin Hunter, consider that the New York 1958 convention was the most important international commercial arbitration agreement among the existing conventions or arbitration agreements.

The reason why this convention is most important relates to the successful and successful application and utilization of national, regional and international Arbitration institutions by the public. The key to the success and success of the role of international commercial arbitration institutions depends on whether or not the implementation of a (foreign) Arbitration award in a country is carried out.

In vain the opinions of experts who state the effectiveness and advantages gained in proceeding through Arbitration in resolving disputes where the implementation of the Arbitration award itself cannot be carried out. Therefore also, the matter of the successful implementation of the Arbitration award is one of the most decisive factors for the development of Arbitration in a country as one of the mechanisms or dispute resolution mechanisms.

One of the reasons the international community entered into and ratified this convention is, partly because the problem of implementing the Arbitration award is still considered difficult to implement in many countries. Therefore the main objective of the convention is to seek foreign arbitration, at least among the participating countries of the convention.

If a court in Indonesia is not willing to implement an Arbitration decision abroad, then our government can be accused of violating the provisions of the convention. Our party can be sued for violating this convention as a participating country. Issues such as these may be brought before the International Court of Justice at Dean Haag. Just like the example we have seen in International Civil Law Jurisprudence, where the Swedish government has been sued by the Dutch government before this International Court of Justice, with the argument that the Swedish government has violated the old Den Haag agreement (1902) on guardianship with no respect a trusteeship decision that has been pronounced outside the Netherlands regarding Boll's child, who was born by a Swedish mother (who has died) and a Dutch father. By placing this Boil child under special education, according to the Dutch government the Convention on Satisfaction has been violated.

Therefore, in order to avoid being accused of an "International Wrong", the Arbitration decisions made by the participating countries of the UN New York Convention should be carried out by this District Court where the party to whom the implementation of the request is based. 


\section{Conclusion}

The conclusions that can be drawn from this paper are:

1. If an international trade dispute occurs, so that the ways of resolution can be reached through non-litigation (alternative litigation) or Alternative Dispute Resolution (ADR). The facilities classified as ADR other than Arbitration facilities as contained in Article 6 of Law No. 30 of 1999 concerning Arbitration and Alternative Dispute Resolution which includes facilities including Meditation facilities, Negotiation facilities, Consolidation facilities, and other facilities. Besides that, there are other considerations that encourage business people to choose the Arbitration method, such as avoiding publicity, to reduce the cost of dispute resolution, to resolve disputes through the use of experts in their field and to avoid unfair dispute resolution. So based on the Arbitration Law it provides an opportunity to resolve trade disputes through the Arbitration institution and it is very appropriate if this institution has a very important role in resolving disputes that occur in the world of international trade.

2. The scope of disputes which can be tried in a trial of the International Commercial Arbitration institution must be related to the issue of trade, finance and general trading (commerce), while those relating to other matters have nothing to do at all.

3. The main provisions which become the jurisdiction of the arbitration court in settling disputes arising in international trade are the legal provisions of the National Law, international special agreements in the field of private law, provisions stipulated by the parties concerned on the basis of autonomy in the private sector, international habits in the private sector and international judicial decisions. Concretely, it can be seen in ICSID or The International Convention on the Resolution of Investment Disputes between the State and Nationals of Other States which was ratified by Indonesia on September 28, 1968.

\section{References}

Adolf, Huala. 1993. Arbitrase Komersial Intemasionat. Cetakan II. Jakarta: Rajawali Pers.

Christoper Pass, Biyan Lowes, Leslie Davies. 1994. Kamus Lengkap Ekonomi, Edisi II. Jakarta: Penerbit Erlangga.

Gautama, Sudargo. 1992. Indonesia dan Arbitrase Intemational. Edisi Revisi. Bandung: Alumni.

M. Husseyn Umar dan A. Supriani Kardono. 1995. Hukum dan Lembaga Arbitrase di Indonesia. Jakarta: Komponen Hukum Ekonomi Elips Projec.

M.S., Amir. 1988. Seluk Beluk dan Teknik Perdagangan Luar Negeri. Seri Umum No. 2. Jakarta: PT. Pustaka Binaman Pressindo,

Muhammad, Abdulkadir. 1993. Pengantar Hukum Perusahaan Indonesia. Bandung: PT. Citra Aditya Bakti.

Poerwadaminta, W.J.S. 1993. Kamus Umum Bahasa Indonesia. Jakarta:.Balai Pustaka.

Redfern, Alan, C.F. dan Hunter Martin. 1986. Law and Practice of International Commercial Arbitration, Sweet and Maxwell, London.

Rubino, Mauro dan Sumartono, International Arbitration Law, Bandung, 1990.

Starke, J.G. 1986. Pengantar Hukum lntemasional, disadur oleh F. Isjwara. Edisi III. Bandung: Alumni.

Subekti, R. 1991. Kumpulan Karangan Hukum Perikatan, Arbitrase dan Peradilan. Bandung: Alumni. 